\title{
DIVERSITY OF TUNISIAN BREAD WHEAT GENOTYPES REVEALED BY MORPHO-AGRONOMICAL AND MICROSATELLITE MARKERS
}

\author{
DIVERSIDADE DE GENÓTIPOS DE TRIGO TUNISIANO PARA PANIFICAÇÃO \\ OBTIDA POR MARCADORES MORFO-AGONÔMICOS E MICROSATÉLITES
}

\author{
Elyes BABAY ${ }^{1,2}$; Ramzi CHAABANE ${ }^{2}$; Rim MZID-ABDMOULEH ${ }^{1}$; M'barek BEN NACEUR $^{\mathbf{2}}$ \\ 1. Laboratoire de Physiologie Moléculaire des Plantes, Centre de Biotechnologie de Borj-Cédria (CBBC), BP901, Hammam-Lif 2050, \\ Tunisia. e.babay@yahoo.fr;_2. Laboratoire de Biotechnologie Appliquée à l'Agriculture, Institut National de Recherche Agronomique \\ de Tunisie (INRAT). Rue Hédi Karray, 2049, Ariana, Tunisia.
}

\begin{abstract}
The genetic diversity of a set of 21 hexaploid wheat germplasm from the National Agronomic Institute of Tunisia were investigated by applying 26 agro morphological traits and 10 wheat microsatellites molecular markers (Simple Sequence Repeat). The morphological variability was analyzed using the Principal Component Analysis (PCA) and the cluster analysis based on ward's method and square Euclidean distance. Eighteen microsatellites primer pairs were tested for all genotypes, among them 10 primers generated polymorphic and reproducible profiles. They revealed a total of 414 reducible bands among which 373 were polymorphic. The polymorphic information content (PIC) values per locus varied from 0,33 to 0,94 with an average of 0,72 . Genetic similarity values between genotypes, calculated by the molecular derived data, were used to produce a dendrogram. The genotypes were clustered in four clear groups according to their origin, pedigree and in some cases to phenotypic characters similarities.
\end{abstract}

KEYWORDS: Genetic diversity. Hexaploid Wheat. Morphological Traits. Microsatellites.

\section{INTRODUCTION}

Bread wheat (Triticum aestivum L.) is a staple food and the major source of calories and protein for a large world population, and is among the most important grain crops in Tunisia. The genetic variability in bread wheat is important for a better improvement of this crop and for the increase of cereal yield in the context of sustainable agriculture to face human needs in the next decades. In Tunisia, the analysis of the agro-morphological traits is an important prerequisite for a responsible and efficient use of germoplasm collections in a breeding program. Moreover, in conjunction with agronomic and morphologic characteristics, the analysis of genetic variability would be a significant contribution to the actions aiming at safeguarding, conservation and breeding. Thus, preservation of genetic diversity of the national wealth could be used by breeders for a future variety development. In order to reach a better characterization of the genetic diversity, it is imperative to use a reliable molecular biology tool for plant breeding and genetic resources management. The molecular diversity study allows us to understand the differences and similarities between the ecotypes, according to their genes. In addition, it describes the structure of genetic variability within populations. Several molecular techniques, to achieve these objectives, are currently available in several laboratories worldwide. Among these techniques, the Simple Sequence Repeats (SSRs) or microsatellites that have been proven to be the markers of choice during the last decade in plant research because of their hyper variability and ease of detection (SINGH et al., 2011). Microsatellites are short sections of DNA where a simple motif, generally $1-5$ bp long is repeated up to about 100 times. Microsatellite markers are highly polymorphic, abundant and fairly evenly distributed throughout eukaryotic genomes (ARIF et al., 2010). There are numerous reports suggesting the usefulness of microsatellite markers for measuring the genetic variability in a wider taxonomic range (CHAN et al., 2008; BANHOS et al., 2008; AZEEM et al., 2012; SPANIC et al., 2012).

Few studies (CHAABANE et al., 2009; CHAABANE et al., 2012) have analysed the pattern of genetic diversity by SSR markers within Tunisian cereals landraces but none was done on bread wheat commonly cultivated in Tunisia. In the present study, we used the SSR markers and the agromorphological traits to investigate the diversity among 21 genotypes within the INRAT germplasm collection. The experiments were conducted at the National agronomic Institute of Tunisia (INAT).

\section{MATERIAL AND METHODS}

Twenty one bread wheat (Triticum aestivum L.) genotypes from the INRAT collection were used in this study (Table 1). The genotypes were sown and grown under rainfed condition in a randomized complete-block design with two replicates per 
genotype, at the experimental field of INRAT, during 2008-2009 season. For data collection the basic morphological data has been compiled from standardized codes of the International Union for the Protection of New Varieties of Plants (UPOV). Twenty qualitative traits were used. These traits were (Growth habit, Flag leaf anthocyanin coloration of auricles, Flag leaf glaucosity, Ear

shape, Spike density, Lower glum shoulder width, Glum shape ,Glum color, beak shape of glum
,Grain shape, Grain colour, Presence of awn, awn divergence, Awn color, Beak thickness, pith in cross section of Straw, Length of first rachis segment, Position of first rachis segment) and nine quantitative (Plant height $(\mathrm{cm})$, Time of emergence, 1000 kernel weight (g), Ear length, Beak length, Flag leaf length, Length of brush hair of grain, Awn length and Beak length ).

Table 1. Pedigrees, origins and years of obtaining of the studied genotypes

\begin{tabular}{|c|c|c|}
\hline Genotypes & Pedigrees & Locality/Year \\
\hline Florance Aurore & Florence/ Aurore & France (Versaille, 1920) \\
\hline Ariana66 & Kenaya338 / Etoile De Choisy & France (Versaille, 1962) \\
\hline Dougga72 & Klein Petiso /Rafaela//2*8156® & Cimmyt/Mexico (1969) \\
\hline Soltane72 & Sonora64/Klein Rendidor & Cimmyt/Mexico (1960) \\
\hline Carthage74 & Napo 63 / Tob "S" // 8156® & Cimmyt/Mexico (1969) \\
\hline L(BT2559) & $\mathrm{Fn} / / \mathrm{K} 50 / \mathrm{N} / 3 / \mathrm{Yr} 70$ & ----------------- \\
\hline Yr70 (Yecora 70) & Cno//Sn64/Klein Rendidor/3/8156® & Cimmyt/Mexico (1970) \\
\hline Sonora64 & Yaktana54/N10b/2*Yaqui54 & Mexico (1964) \\
\hline Saada & Butte //Arthur/Butte & Maroc \\
\hline Richelle Hative110 & Selected From Wheat "Tuzelle Allora" & Australia \\
\hline Castan & Mara, Ita//Crystal/Champlein/3/Rallye & France (1976) \\
\hline Mona & Plowmans-3/Canberra & Australia (1933) \\
\hline Soudous 1 & 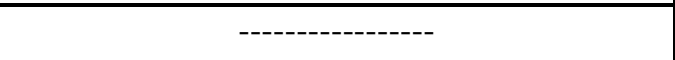 & 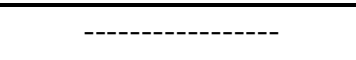 \\
\hline Tebica & Seri/Buc “S“ & Icarda/ Syria (1990) \\
\hline Utique & $(\mathrm{Nd} / \mathrm{Vg} 9144 / / \mathrm{Kal} / \mathrm{Bb} / 3 / \mathrm{Yaco} / 4 /$ Vee $)$ & Cimmyt/Mexico (1989) \\
\hline $\mathrm{T} 88-255$ & $\begin{array}{c}\text { (Pvns /Sprw"S"/5/Pata/On// } \\
\text { Maya74/4/Bb/3/Pato//Inia/Napo) }\end{array}$ & Cimmyt/Mexique \\
\hline Kavkaz & (Kvz / Buho // Kal / Bb) & Russia (1972) \\
\hline Fath 75 & (Cno/Gll) & Tunisia (1973) \\
\hline Bow"S” (Bobwhite) & $(\mathrm{Au} / / \mathrm{Kal} / \mathrm{Bb} / 3 / \mathrm{Wop})$ & Cimmyt/Mexico (1973) \\
\hline Wop (Woodpecker) & (Inia66/Napo//2*Cal/3/Pv18/Cno) & Cimmyt/Mexico (1975) \\
\hline Blue Bird (Bb) & (Cno//Sn64/Klre/3/8156 & Cimmyt/Mexico (1969) \\
\hline Mahon 73 & Old Tunisian variety & Tunisia (1937) \\
\hline "Baroota52" & Mixture Introduced From Australia & Tunisia (1913) \\
\hline "Guelma" =Eap & Mentana-26/Florence 46 & Tunisia \\
\hline Florence 46 & White-Naples//Fife/White-Naples/3/Fife/Eden & Australia(1906) \\
\hline Ias-20-Pato & Ias20/Pato & Brazil \\
\hline
\end{tabular}

For each genotype, the extraction of total genomic DNA was performed from leaves according to protocol used by Kiran et al. (2008). Ten microsatellite primer pairs were selected (Table 2). PCR reactions were carried out in total reaction mixture of $25 \mu \mathrm{l}$ containing $50-100 \mathrm{ng}$ of DNAg as template, 1X Green GoTaq Reaction Buffer (Promega), 0,2 mM dNTPs and $0.25 \mu \mathrm{M}$ of each primer and 1 Unit of GoTaq DNA Polymerase (Promega). The amplifications were performed in a 
Biometra Thermocycler (Germany) with the following cycling: one cycle of $95^{\circ} \mathrm{C}$ for $3 \mathrm{~min}, 35$ cycles of $1 \mathrm{~min}$ denaturing step at $94^{\circ} \mathrm{C}, 1 \mathrm{~min}$ annealing temperatures between 51 and $61^{\circ} \mathrm{C}$ (Table 2) depending on the primers and 2 min extension at $72^{\circ} \mathrm{C}$, followed by $10 \mathrm{~min}$ of final extension at $72^{\circ} \mathrm{C}$. Amplified PCR products were separated by using 3\% agarose gel electrophoresis in 1xTrisBorate-EDTA buffer ( $\mathrm{pH}$ 8.3). To confirm some results, SSR products were also separated using $6 \%$ non-denaturing polyacrylamide gel electrophoresis in 1x TBE buffer. A 100bp DNA Ladder (Promega) was used as a molecular size standard.

Table 2. Primers used, their chromosomes locations, PIC values, allels number generated polymorphism percentage and annealing temperature

\begin{tabular}{|c|c|c|c|c|c|}
\hline Primers & Chr & PIC & Nb Allels & $\begin{array}{c}\text { Poly } \\
(\%)\end{array}$ & $\begin{array}{c}\text { Ta(C } \\
\mathbf{(}\end{array}$ \\
\hline WMC14 & 7D & 0,77 & 6 & 0.30 & 61 \\
\hline WMC 17 & 7A & 0,69 & 8 & 0.28 & 56 \\
\hline WMC 18 & 2D & 0,87 & 5 & 0.23 & 61 \\
\hline WMC 21 & -- & 0,84 & $4+1($ null $)$ & 0.25 & 61 \\
\hline WMC 24 & 1A & 0,92 & 5 & 0.20 & 51 \\
\hline WMC 25 & 2B & 0,33 & 4 & 0.50 & 51 \\
\hline WMC 27 & 2B, 2D & 0,48 & 6 & 0.46 & 60 \\
\hline WMC 48 & 4A, 4B, 4D & 0,59 & 7 & 0.42 & 61 \\
\hline WMC 50 & 3A & 0,94 & 5 & 0.19 & 61 \\
\hline WMC 283 & 4A,7A & 0,76 & 3 & 0.36 & 61 \\
\hline
\end{tabular}

Chr: chromosome. PIC: polymorphism information content; Nb: number. Ta: temperature of annealing.

The morphological variability was analyzed using the Principal Component Analysis (PCA). The Pearson correlation coefficients $(\alpha=0.05$, standard PCA without rotation of axes) were calculated by using the software XLSTAT 7.5.2 (Addinsoft, http://www.xlstat.com/en/home). The SSR profiles were transformed into a binary matrix where the presence of the generated band at a precise level is scored as 1 and its absence is scored as 0. A data matrix was prepared for the analyses. A pair-wise similarity matrix was generated with the software NTSYSpc-2.02j (NTSYS-Numerical Taxonomy and Multivariate Analysis; ROHLF 1998) using the simple matching coefficient (SOKAL et al., 1958). A dendrogram was then drawed using the UPGMA (Unweighted Pair-Group Method using Arithmetic Averages) cluster analysis.

The PIC (Polymorphism Information Content), according to BOSTEIN et al. (1980), is calculated by the following formula: PIC $=1-\Sigma$ $p^{2} i$ where $\mathrm{Pi}$ is the proportion of the population carrying the ith alleles, scored for each locus.

\section{RESULTS AND DISCUSSION}

The first three PCA axes accounted for $47 \%$ of the total variability expressed by morphological traits. The first component accounts for $23.1 \%$ of the total variation. It is determined mainly by the presence of awn, awn divergence and Beak thickness. The second, which absorbs $12.3 \%$ of the total variation, is strongly correlates with characteristics (length of first rachis segment and flag leaf length). By absorbing $11.6 \%$ of the variability, the third component is also defined by a strong correlation to the glum shape and Time of emergence. The major correlated variability of genotypes is showed by the axes 1 and 2 which explained $35.37 \%$ of the total variability and revealed 6 groups (Figure 1).

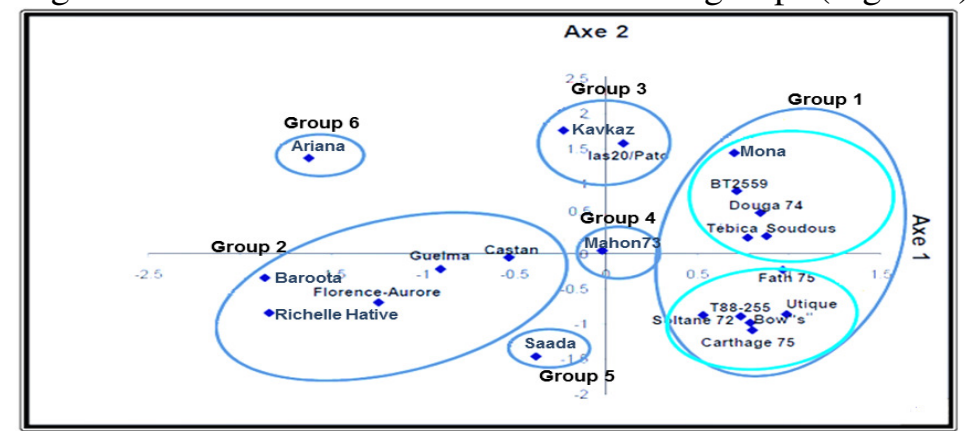

Figure 1. Principal component analysis (PCA) of morphological data (Axes 1 and 2) 
The Euclidean distance ranged from 1.27 to 24.87 between Fath 75 and Bow"s", and between Ariana and Bow"s", respectively (Figure 2). The range of Euclidean distance among the genotypes was relatively wide. This result indicated that the amount of phenotypic variation among these genotypes was relatively high. These, also reflect the genetic diversity of the loci controlling these traits. Cluster analysis was done based on ward's method and square Euclidean distance, and the genotypes were separated in two distinct clusters. According to this analysis, whereas, genotypes Fath 75, Bow"S", T88-255, Utique, Tebica, Soudous, BT2559, Soltane72, Dougga72, Ias-20/Pato, Mona, Kavkaz and Carthage74 were placed in the first group, genotypes Florence Aurore, Guelma, Baroota52, Richelle Hative, Castan, Saada and Ariana in the second group. A genotype Mahon73 remains out of groups since it is morphologically very different from all others (Figure 2).

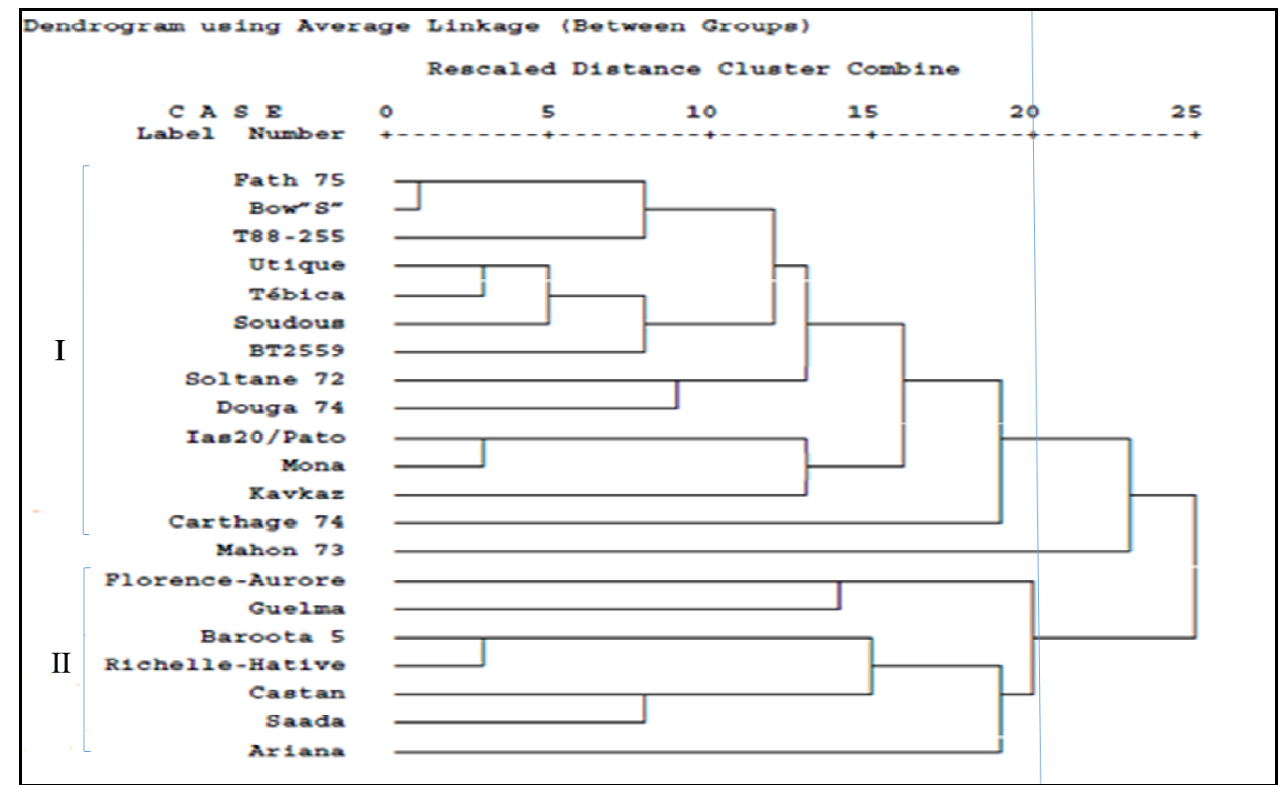

Figure 2. Cluster analysis using ward method and squared Euclidean distance (Morphological traits)

The percentage of the phenotypic variation is explained by the first three components. The analysis of the agro-morphological traits, apparently was not very efficient through the PCA procedure, this is can be explained by the relatively large number of morphological parameters (29 characters) used and the variation of the origins of genotypes (Table 1). This phenotypic diversity reflects the board genetic diversity between genotypes.

All the agro-morphological characteristics recorded have shown a significant $\mathrm{F}$ for the factors analyzed (i.e., years, locations, accessions and the interactions among them). Therefore, well-defined cultivars adapted to local environments are developed for specific areas. These results confirmed the previously published by Acharya et al. (2010) which reported that the characteristics of plant material can vary depending on the genotype, environment under which they are grown and the interaction between the previous two factors.

Eighteen microsatellites primers pairs were tested for all genotypes. Among these primers six primers generated monomorphic profiles; two primers showed null alleles and 10 primers (table 2) generated polymorphic and reproducible profiles, covering 10 wheat chromosomes. These profiles generated were used to study the genetic diversity among the 21 wheat genotypes. Thus, a total of 414 reducible bands among which 373 were polymorphic, with an average of 18.81 bands/genotype and 0.72 PIC average. A PIC values for all primers is provided in table 2. The dendrogram obtained using these microsatellites data, based on the similarity matrix. At genetic similarity (GS) of about 74\%, the dendrogram based on SSR data discriminated the variety "Kavkaz" and the genotype IAS-20-Pato from the rest of the analysed genotypes, which were clustered in four major groups of similar genotypes (Figure 3). The first group (Gr1) is composed of the following varieties: "Florence Aurore" "Ariana 66", "Douga 74","Soltane 72"," Carthage 74", "BT2559", "Saada" and "Richelle hative 110". The second group (Gr2) contains "Castan","Mona", "Soudous1", "Tébica","L (T88-255)"and"Utique96". The group (Gr3) is formed by the varieties "Fath75", L (BOW "S") and "Mahon 73". The fourth group (Gr4) is composed of two varieties "Baroota52" and 
"Guelma". After reviewing the origin and the pedigree of the varieties collected in these groups, we noticed that some grouped varieties have common relative parents or same origin. In fact, the varieties "Florence-Aurore" and "Ariana 66", grouped at high genetic similarity $(\mathrm{GS}=85 \%)$, are both from Versailles (France) and their selection was held in same period (1922). Furthermore, there is a relationship between "Ariana 66" and our bread wheat varieties, in particular "Douga 74" (Deghais et al. 1997). "Douga 74", "Carthage 74" and "Soltane 72» are from CIMMYT and have some parents in common. "Douga 74" and "Carthage 74" are in the same group (Gr1) at high genetic similarity coefficient (CS=91\%). Both "Douga 74" and "Carthage 74» have a same direct parent (8156®). Klein Rendidor parent of "Soltane 72" is was often used in programs of CIMMYT as a source of resistance to septoria. Klein Rendidor has the same parent of Klein Petiso (KLEIN-33) and both are from Argentina. Klein Petiso is one of the parents of "Douga 74". This may explain the high degree of similarity (83\%) between "Douga 74" and "Soltane 72". "YR70" is a direct parent of "BT2559", its pedigree is NOC // SN64/Klein rendidor/3/8156@. This can explain firstly its proximity to "Soltane72" (SN64 / rendidor Klein) with a high genetic similarity coefficient (about 91\%) through their direct relatives It confirms its high genetic similarity $(\mathrm{GS}=89 \%)$ with the variety "Carthage 74» through a direct relative ("8156 ®"). The varieties "soltane72" and "BT2559" have a common parent ("Sonora64"), which stemmed from crossing: Yaktana54 /N10B /2*Yaqui54. By Yaqui54 and Yaktana54, it goes back to wheat "Marroqui588" (synonym to "Florence-Aurore") (DEGAIS et al., 1997). This could explain the clustering of "Soltane72" and "BT2559"with "Florence-Aurore" in the first group. The variety "Saada" is also in the first group, the only information we have about, is obtained from a breeding program of INRA Morocco. "Richelle Hative 110" and "Florence 135" are from Australia. Florence 135 was expelled in the early 40's and used like a parent of "Florence Aurore" (very high quality). These two varieties are phenotypically very similar. The Australian origin of "Florence-Aurore", the name and these phenotypical similarities explain the clustering of "Richelle Hative110" and "Florence Aurore".

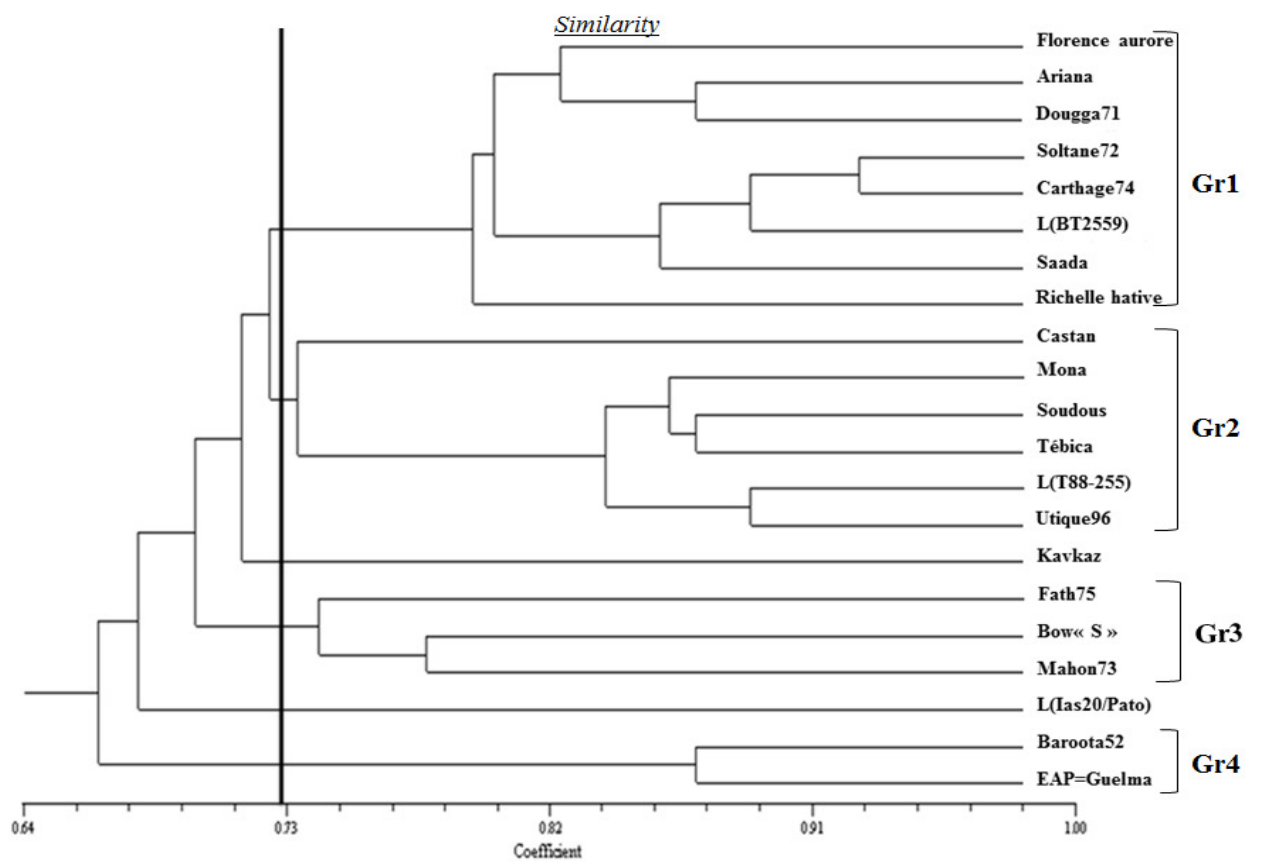

Figure 3. Dendrogram of genetic similarities based on UPGMA method

In the second group (Gr 2) (Table 1), Tébica, Utique 96 and "T88-255" have a similarity coefficient around $85 \%$. These genotypes derived from crosses made in CIMMYT (Mexico), share the same agronomic traits, namely the productivity and diseases tolerance (especially Septoria, leaf rust, stripe rust and powdery mildew). Furthermore, they have some common parents. "Utique96" and "T88-
255" have "BLUE BIRD" (Bb) as a common ancestor (Table 1). Similarly, "Tébica" and "Utique 96" have a common ancestor which is the variety Veery $($ VEE) $($ Veery $=$ Seri). Physiologically, these two varieties ("Utique 96" and "Tébica") showed a high tolerance to salinity (Hannachi 2008). "Mona" and "Soudous1" belong to the second group, their genetic similarity at microsatellites level reflect their 
similarity for several measured traits such as: Height of stalks, length of flag leaf, length and colour of beard; Length, colour, beak shape of the glume and the same grain characteristics.

The Russian variety "Kavkaz" (KVZ) discriminated from all the others, its widely used in breeding programs at CIMMYT. It is genetically closer to groups $2(\mathrm{GS}=72 \%)$ than others groups. Its proximity to Gr 2 could be explained by the fact that Veery (VEE) (parent of "Utique 96" and "Tébica" ) derived from the crossing; KVZ / BUHO // KAL / BB.

The Third group with (GS=75\%) is formed by the varieties "Fath 75", "Bow"S" and "Mahon 73". "Mahon 73", from the Balearic Island, is the oldest and the most cultivated wheat variety in Tunisia (1910). The variety "Bow"S" called (Bobwhite) has long been used in crosses and genetic improvement of wheat in Tunisia. Their direct parents are "WOP" and "Bb" (Table 1).The variety "Bow"S" has the same rear parents "CNO" from both paternal and maternal sides. This could explain its high similarity with the variety "Fath75" (CNO/GLL). The three varieties "Fath75", "Bow"S" and "Mahon 3" share some phenotypic characteristics (several traits for the spike: same length of the ears, shape and length of beak shape of glume. etc.). This could explain their genetic clustering within the same group.

The fourth group contains two varieties "Baroota52" and "Guelma" with a high coefficient of similarity (87\%). "Baroota52" is from Australia, introduced in Tunisia in 1913 and cultivated after selection in 1923. "Guelma" is the result of crossing of Mentana-26 and Florence 46 (from Australia). These two varieties (Gr4) share more several morphological and physiological traits that could explain more their high genetic similarity. For example, they have the same height of the stems and the same length of the ears and brush. They also stand upright leaf flags. In addition, the two varieties are resistant to septoria and great sensitivity to lodging. All these factors could explain the clustering of "Guelma" with "Baroota52".

\section{CONCLUSIONS}

Both molecular and agro-Morphological techniques are complementary to better characterize and study the diversity of wheat and all cereal species.

The genetic diversity obtained by SSR marker is relatively consistent and compatible with a pedigree and a geographical origin of genotype. SSR molecular-marker can be successfully employed in assaying the level of polymorphism and diversity.

The characterization of some bread wheat genotype using morphologic and SSR markers may provide useful information for long term improvement in yield, qualities, resistance (biotic and abiotic stresses) and for germplasm identification and conservation.

\section{ACKNOWLEDGMENTS}

This research was supported by a Grant from the Tunisian Agricultural Ministry We thank Dr. Mouldi EL FALEH and Mohamed Salah EL GHARBI (Field Crop Laboratory, INRAT) for providing some wheat materials and Prof. Hammadi BEN SALAH (Field Crop Laboratory, INRAT) for his great help in morphological analysis.

RESUMO: A diversidade genética de um conjunto de 21 hexaplóides em germoplasma de trigo oriundo do Instituto Nacional da Tunísia foi investigada pela aplicação de 26 caracteres morfológicos e 10 marcadores de microsatélites (Sequências simples repetidas). A variabilidade morfológica foi analisada pelo uso da análise de componentes principais (ACP) e análise de agrupamento baseada no método de Ward e o quadrado da distância Euclidiana. Dezoito primers de microsatélites foram testados para todos os genótipos, entre os quais 10 geraram polimorfismo e grupos distintos. Eles demonstraram um total de 414 bandas entre as quais 373 foram polimórficas. Os valores de polimorfismo encontrados por locus (VPL) variaram entre 0,33 a 0,94 com uma média de 0,72 . Os valores da similaridade genética calculada para os dados moleculares originaram um dendograma. Os genótipos foram agrupados em quatro grupos de acordo com sua origem, pedigree (descendência) e em alguns casos pelos caracteres da similaridade fenotípica.

PALAVRAS-CHAVE: Diversidade genetic. Hexaplóide. Caracteres morfológicos. Microsatélites. 


\section{REFERENCES}

ACHARYA, S. N.; BASU1, S. K.; DATTA, S.; BANIK.; PRASAD, R. Genotype x environment interactions and its impact on use of medicinal plants. Open Nutraceuticals Journal, n. 3, p. 47-54, 2010.

ARIF, I. A.; KHAN, H, A.; SHOBRAK, M.; AL HOMAIDAN, A. A.; AL SADOON, M.; AL FARHAN, A. H.; BAHKALI, A. H. Interpretation of electrophoretograms of seven microsatellite loci to determine the genetic diversity of the Arabian Oryx. Genetics and Molecular Research, v. 9, n. 1, p. 259-265, 2010. http://dx.doi.org/10.4238/vol9-1gmr714

AKRAM, A.; IQBAL KHAN, A.; AWAN, F. S.; REHMAN, A.; AHMAD, F.; MALIK, A.; RAO, S. Genetic diversity in Indian sub-continental landrace cultivars of the genus Triticum L. African Journal of

Biotechnology, v. 11, n. 44, p. 10170-10175, 2012.

BALFOURIER, F.; RAVEL, C.; BOCHARD, A. M.; BOUTET, G.; SOURDILLE, P.; DUFOUR, P.; CHARMET, G. Développement, utilisation et comparaison de différents types de marqueurs pour étudier la diversité parmi une collection de blé tendre. Les actes du Bureau Des Ressources Génétiques, n. 6, p. 129$144,2006$.

BANHOS, A.; HRBECK, T.; GRAVENA, W.; SANAIOTTI, T. Genomic resources for the conservation and management of the harpy eagle (Harpia harpyja, Falconiformes, Accipitridae). Genetics and Molecular Biology, v. 31, n. 1, p. 146-154, 2008. http://dx.doi.org/10.1590/S1415-47572008000100025

CHAN, CH.; ZHAO, Y.; CHEUNG, MY.; CHAMBERS, GK. Isolation and characterization of microsatellites in the kakerori (Pomarea dimidiata) using feathers as source of DNA. Conservation Genetics, v. 9, n. 4, p. 1067-1070, 2008. http://dx.doi.org/10.1007/s10592-007-9456-2

CHAABANE, R.; KHOUFI, S.; KHAMASSI, K.; DA SILVA, J. T.; BEN NACEUR, A.; BCHINI, H.; BABAY, E.; OUJI, H.; BEN SALAH, H.; GHARBI, M. S .; BEN NACEUR, M. Molecular and Agrophysiological Approaches for Parental Selection before Intercrossing in Salt Tolerance Breeding Programs of Durum Wheat. International Journal of Plant Breeding, v. 6, n. 2, p. 100-105, 2012.

CHAABANE, R.; EL FELAH, M.; BEN SALAH, H.; BEN NACEUR.; ABDELLEY, C.; RAMLA, D.; NADA, A.; SAKER, M.; Molecular characterization of Tunisian barley (Hordeum Vulgare L.) genotypes using microsatellites (SSRs) markers. European Journal of Scientific Research, v. 36, n. 1, p. 6-15, 2009.

DEGHAÏS, M.; KOUKI, M.; GHARBI, M. S.; EL FELAH, M. Les Variétés de céréales cultivées en Tunisie, National Imprimerie of Edition (Eds), Tunisia, P. 445, 2007.

DEGHAÏS, M. Le blé tendre en Tunisie. Annales de l'Institut National de la Recherche Agronomique de Tunisie, Special edition, Tunisia, p. 286, 1996.

HANNACHI, S. Evaluation de la tolérance à la salinité d'une collection de Blé tendre : approche physiologique et biochimique. Institut Nationale Agronomique de Tunis. Tunisia, P.79, 2008.

KAUL K. Isolation and purification of genomic DNA from withania somnifera for analytical applications. International Journal of Biotechnology \& Biochemistry, v. 4, n. 2, p. 151-157, 2008.

NEI, M.; LI, W. H. Mathematical model for standing genetic variation in terms of restriction endonucleases.

Proceedings of the National Academy of Sciences of the United States of America, v 76 n 10, p.5269-5273, 1979. http://dx.doi.org/10.1073/pnas.76.10.5269

ROHLF, F J. NTSYS-pc: numerical taxonomy and multivariate analysis system Version 2.0. Applied Biostatistic, New York, N.Y, 1998. 
SINGH, R.; SHEORAN, S.; SHARMA, P.; CHATRATH, P. Analysis of simple sequence repeats (SSRs) dynamics in fungus Fusarium graminearum. Bioinformation, v. 5, n. 10, p. 402-404, 2011.

http://dx.doi.org/10.6026/97320630005402

SINGH, R. K.; SINGH, R. B.; SINGH, S. P.; SHARMA, M. L. Identification of sugarcane microsatellites associated to sugar content in sugarcane and transferability to other cereal genomes. Euphytica, v. 182, n. 3, p. 335-354, 2011. http://dx.doi.org/10.1007/s10681-011-0484-0

SOKAL, R. R.; MICHENER, C. D. A statistical method for evaluating systematic relationships. The University of Kansas science bulletin, v. 38, n. 2, p. 1409-1438, 1958.

VALENTINA, S.; HERMANN, B.; GEORG, D. Assessment of genetic diversity of wheat genotypes using microsatellite markers. Periodicum Biologorum, v. 114, n. 1,p. 37-42, 2012. 